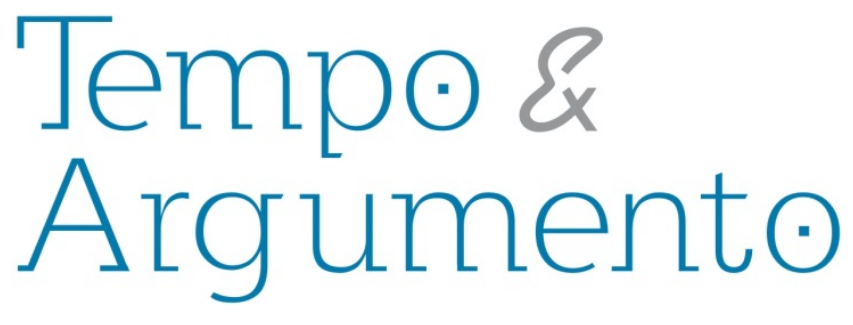

\title{
As charges antiperonistas de Tribuna da Imprensa (1949-1955)
}

\begin{abstract}
Resumo
Este artigo analisa as charges sobre o governo Juan Domingo Perón produzidas pela artista alemã Hilde Weber (1913-1994) para o jornal carioca Tribuna da Imprensa, no período de 1949 a 1955. Busca-se identificar como o humor foi utilizado para transmitir determinadas mensagens políticas e as relações delas com a posição político-partidária do periódico, cuja propriedade e direção estavam nas mãos de Carlos Lacerda, político e jornalista filiado à União Democrática Nacional (UDN). Profundamente antiperonista, Tribuna da Imprensa divulgou principalmente representações que destacavam o presidente argentino como déspota, conspirador, tolo e malandro. Nas charges assinadas por Hilde Weber fica implícita a personalização da experiência política justicialista, ao apontar uma única pessoa como principal responsável pela destruição das instituições democráticas. Também é visível que o jornal usava o noticiário negativo sobre o país vizinho como arma para a luta político-partidária em nível nacional. Carlos Lacerda, em especial, atuava como um dos principais opositores a políticos trabalhistas, como Getúlio Vargas e João Goulart, que, na sua visão, poderiam conduzir o Brasil a uma trajetória política semelhante à da Argentina peronista.
\end{abstract}

Palavras-chave: Caricaturas e Desenhos Humorísticos; Peronismo; Imprensa - Argentina; Argentina - Política e Governo; Carlos Lacerda.

\author{
Rodolpho Gauthier Cardoso dos Santos \\ Doutor em História Social pela \\ Universidade de São Paulo (USP). \\ Professor do Instituto Federal de Minas \\ Gerais (IFMG). \\ Brasil \\ rodolpho.santos@ifmg.edu.br
}

\section{Para citar este artigo:}

SANTOS, Rodolpho Gauthier Cardoso dos. As charges antiperonistas de Tribuna da Imprensa (1949-1955). Revista Tempo e Argumento, Florianópolis, v. 8, n. 18, p. 215 - 248. maio/ago. 2016.

\author{
DOI: $10.5965 / 2175180308182016215$
}

http://dx.doi.org/10.5965/2175180308182016215 


\title{
Anti-Peronist cartoons by Tribuna da Imprensa (1949-1955)
}

\begin{abstract}
This article analyzes the editorial cartoons about the Juan Domingo Peron's administration produced by the German artist Hilde Weber (1913-1994) for the Carioca newspaper Tribuna da Imprensa, within the period from 1949 to 1955. We seek to identify how humor was used to convey certain political messages and their relations with the political and party-based position of the newspaper, whose ownership and management were in the hands of Carlos Lacerda, politician and journalist affiliated to the União Democrática Nacional (UDN). Deeply anti-Peronist, Tribuna da Imprensa mainly reported representations highlighting the Argentine President as a despot, conspirator, naive, and scoundrel man. In the editorial cartoons signed by Hilde Weber there is an implicit embodiment of the Justicialist political experience, pointing out a single person as the main responsible for destroying the democratic institutions. It is also noticeable that the newspaper used the negative news about the neighboring country as a weapon for political and partisan struggle nationwide. Carlos Lacerda, especially, acted as one of the main opponents of labor politicians, like Getúlio Vargas and João Goulart, who, according to their perception, could lead Brazil to a political trajectory similar to that of Peronist Argentina.
\end{abstract}

Keywords: Editorial Cartoons; Peronism; Press - Argentina ; Argentina - Politics and government; Carlos Lacerda.

\section{Introdução}

Nascido em dezembro de 1949, o diário carioca Tribuna da Imprensa notabilizou-se, entre outros aspectos, por seu profundo antiperonismo. A embaixada argentina no Rio de Janeiro chegou a apontá-lo, em ofício reservado, como um dos meios de comunicação que praticavam a oposição ao governo argentino de forma mais "radical e permanente" (1954 apud ALMEIDA, 2005, p. 149). Fundado e dirigido pelo jornalista e político Carlos 
Lacerda, o periódico estava alinhado a uma ala da União Democrática Nacional (UDN), partido liberal-conservador que combatia com veemência o getulismo e o comunismo.

Foram parte importante da produção de Tribuna da Imprensa as charges publicadas na página quatro, ao lado do editorial. Eram, em sua maioria, obras da artista alemã Hilde Weber (1913-1994), que assinava apenas como Hilde.

Desde o século XIX, essa forma específica de humor gráfico, em sua linguagem peculiar, passou a ser intensamente instrumentalizada para a política. Ao longo do século $X X$, as charges se consolidaram como parte importante de tais disputas. Com frequência, alcançaram grande repercussão ao zombar de homens públicos, mostrando-os não como seres sacralizados, mas permeados de defeitos. Embora feitas para compreensão imediata, tornaram-se importante instrumento de intervenção pública cuja importância ultrapassava o riso fugaz. A respeito desse tipo de fonte histórica, escreveu Rodrigo Patto Sá Motta (2006, p. 19):

A fácil adaptação da caricatura ao discurso jornalístico deveu-se [...] ao fato de ter funcionado como crônica política. O desenho de humor, de maneira recorrente, atua no comentário diário dos acontecimentos e atos dos líderes políticos, o que auxilia os jornais em seu papel de produzir a notícia e informar o grande público. Com frequência, as caricaturas servem para expressar o ponto de vista do periódico sobre os temas em debate, como se ilustrassem a posição política do jornal.

Não é possível compreender as charges ou caricaturas políticas, como prefere Motta (2006), sem levar em conta as próprias disputas político-partidárias de cada período. Em razão disso, apresenta-se a seguir uma breve introdução a respeito da Argentina e do Brasil naqueles anos.

O coronel argentino Juan Domingo Perón (1895-1974) destacou-se inicialmente como membro de um grupo militar nacionalista, anticomunista e ultracatólico que foi responsável por um golpe de estado em 1943 (PLOTKIN, 2013, p. 49). Durante os quase três anos de governo autoritário do Grupo de Oficiales Unidos (GOU), acumulou os cargos de vice-presidente, Ministro da Guerra e Secretário do Trabalho. Foi nesta última função que adotou políticas favoráveis aos trabalhadores que se assemelhavam às de Vargas, 
político que afirmou repetidas vezes admirar. Estabeleceu, entre outras medidas, férias remuneradas e o aguinaldo, remuneração extra no final do ano (equivalente ao $13^{\circ}$ salário no Brasil).

A enorme popularidade veio acompanhada de proporcional oposição. Perón passou a ser duramente criticado por setores das oligarquias tradicionais e dos grupos industriais. Embora tenha estabelecido aliança com uma ala do movimento sindical, por meio da Confederación General del Trabajo (CGT), foi atacado por associações de trabalhadores ligadas aos socialistas e comunistas argentinos. Foi alvo, ainda, de agremiações e partidos liberais, vinculados à classe média e a estudantes universitários, que combatiam a ditadura do GOU e a associavam ao nazifascismo.

Os protestos internos e externos contra sua atuação levaram à sua renúncia forçada e prisão, em outubro de 1945, por ordem do então presidente da república, o general Edelmiro Farrell. Em reação, no dia 17 daquele mês, uma multidão operária e sindical concentrou-se em frente à Casa Rosada para exigir sua libertação sob ameaça de greve geral. Livre e ovacionado, o popular coronel anunciou meses depois que concorreria às eleições presidenciais, que marcariam o retorno do país à democracia1.

Na campanha de 1946, marcada por intensa polarização, Perón articulou uma coalizão de forças heterogêneas, que teve como base o Exército, a Igreja Católica, grupos conservadores nacionalistas e os trabalhadores, sobretudo aqueles que pertenciam à CGT. A interferência da diplomacia estadunidense no pleito, por meio da atuação do embaixador norte-americano Spruille Braden, foi habilmente utilizada por Perón, que argumentou que seus concorrentes não passavam de grandes oligarcas e títeres da

\footnotetext{
${ }^{1} \mathrm{O}$ historiador argentino Mariano Ben Plotkin (2013, p. 97-143) demonstrou como o peronismo se apropriou e reformulou a memória a respeito desse evento histórico (17/10/1945), de modo a integrá-lo ao seu imaginário político. A partir de 1946, o 17 de outubro passou a ser comemorado nacionalmente como "Dia da Lealdade" em cerimônias controladas pelo Estado e realizadas principalmente na Praça de Maio, em frente à Casa Rosada. Em uma tentativa de reformulação da memória coletiva, a propaganda peronista, ao longo dos anos, ampliou bastante a participação de Eva Perón naqueles eventos e diminuiu a importância dos sindicatos, enfatizando a espontaneidade do povo, que teria estabelecido uma relação direta com seu líder. Nos rituais suntuosos e meticulosamente organizados pelos peronistas, os eventos de 17 de outubro foram romantizados e reforçados como a fonte original de legitimidade do poder de Perón.
} 
potência capitalista. A estratégia funcionou e ajudou-o a vencer, com quase 53\% dos votos, em fevereiro de 1946.

A Argentina possuía então muitas reservas, acumuladas em decorrência dos saldos comerciais positivos obtidos durante a Segunda Guerra. Esses recursos financiaram a política peronista de distribuição de renda e de forte intervenção do Estado na economia. Foram nacionalizadas as ferrovias e serviços como o fornecimento de energia elétrica e telefonia.

No início da Guerra Fria, o país declarou a terceira posição em relação à política externa. Profundamente nacionalista, Perón não se alinharia geopoliticamente aos Estados Unidos nem à União Soviética (CAVLAK, 2008, p. 45). Ele dizia, em seus discursos, que sua ideologia não era capitalista ou comunista, mas justicialista, por enfatizar a busca da justiça social. Tal qual Vargas, costumava lembrar aos empresários que as medidas de cunho social tomadas pelo Estado eram a melhor forma de evitar a repetição dos acontecimentos russos de 1917.

Nesse período, a Argentina buscou, sobretudo no nível discursivo, equidistância em relação ao que chamou de "dois imperialismos". Ao contrário do que ocorreu no Brasil, o Partido Comunista argentino, embora tenha sofrido com prisões e fechamento de jornais, não foi proscrito em nenhum momento. Para a diplomacia estadunidense, a política externa platina passou a ser uma pedra no sapato.

Durante o primeiro mandato (1946-1951), foi montada uma ampla e bem articulada estrutura de propaganda oficialista, que incluía controle sobre grande número de meios de comunicação (CAPELATO, 2008). Também houve fortalecimento do Poder Executivo, limitação das liberdades políticas, prisão de opositores e censura aos meios de comunicação. Nas palavras do sociólogo argentino Juan Carlos Torre (2002, p. 53), ocorreu ao longo dos anos um processo "sistemático [de] atrofiamento do pluralismo político e das liberdades públicas". Aproveitando-se do bom momento econômico, o peronismo liderou, em 1949, uma ampla reforma da Constituição, que incorporou direitos sociais e garantiu a Perón ilimitadas tentativas de reeleição. 
A partir da década de 1950, o presidente argentino passou a insistir publicamente no Pacto $A B C$, uma iniciativa de integração econômica composta por Argentina, Brasil e Chile. De acordo com ele, os três países tinham economias complementares e sua união seria a única forma de contrabalançar o futuro e inevitável ataque das superpotências às nações detentoras de amplos recursos naturais. O projeto de integração, que provocou muita polêmica, contrariava abertamente os interesses estadunidenses, para quem a união continental pan-americana seria a forma mais eficiente de barrar a expansão comunista.

Em 1951, Perón foi reeleito para um segundo e inconcluso mandato. A economia argentina, no entanto, começou a dar claros sinais de enfraquecimento, que se refletiram na popularidade do governo ${ }^{2}$. Em setembro daquele ano ocorreu a primeira tentativa frustrada de golpe militar. A partir de 1954, Perón também viu a Igreja Católica, cujo apoio fora fundamental nos primeiros anos, juntar-se à oposição. Entre os muitos motivos que levaram ao rompimento estão a interferência do regime nas escolas, as acusações do presidente contra sacerdotes antiperonistas e a difusão de propaganda a respeito de um “cristianismo peronista”, que era independente da tradição católica e incluía a devoção popular a Evita, morta de câncer em 1952 (TORRE, 2002, p. 68-69). A forte influência que a Igreja Católica exercia sobre círculos da alta hierarquia militar ampliou os insatisfeitos com os rumos políticos do país.

Os conflitos políticos se acirraram especialmente no ano de 1955. Em junho, edifícios do centro de Buenos Aires foram bombardeados, em uma tentativa frustrada de militares de assassinar o presidente que resultou na morte de 364 pessoas. $\mathrm{O}$ “Massacre da Praça de Maio" ampliou ainda mais a polarização ideológica. Em 16 de setembro, uma nova rebelião, liderada principalmente pelo Exército e pela Marinha, derrubou Perón. As forças vencedoras chamaram o processo de "Revolução Libertadora". Nos anos

\footnotetext{
${ }^{2}$ O fortalecimento da oposição na sociedade argentina veio acompanhado da ampliação das dificuldades econômicas, principalmente a partir de 1952. Para fazer frente à inflação e ao déficit fiscal, o governo anunciou o II Plano Quinquenal, que inclúa a diminuição dos investimentos públicos, o aumento dos impostos, o congelamento dos salários e o controle de preços. Nos discursos de Perón, o racionamento de carne e de farinha de trigo foi justificado pela necessidade de sacrifícios diante dos novos tempos.
} 
seguintes, medidas autoritárias buscaram em vão banir qualquer referência ao justicialismo do sistema político argentino.

O Brasil também viveu anos conturbados. A derrubada do Estado Novo, em outubro de 1945, acelerou o processo de redemocratização. Meses antes, haviam sido criados pelo menos três grandes partidos: o Partido Social Democrático (PSD), o Partido Trabalhista Brasileiro (PTB) e a União Democrática Nacional (UDN). Os dois primeiros, embora bastante diferentes, estiveram, em sua origem, mais ligados ao getulismo e à complexa rede de alianças construída por ele.

A UDN surgiu a partir da oposição a Getúlio Vargas e teve apelo principalmente entre as elites, além de atrair parte significativa da classe média urbana e da população rural de regiões dominadas por líderes oligárquicos antigetulistas. Ideologicamente, apresentou como traço central o liberalismo com ênfase no livre mercado, no direito à propriedade privada e em outros direitos individuais. De modo geral, seus correligionários defendiam a democracia e colocavam-se contra o fascismo e, principalmente, o comunismo. No entanto, o liberalismo udenista carregava "feição indisfarçavelmente elitista", evidente nas reservas quanto à extensão da participação popular e nos contínuos apelos de alguns de seus membros à intervenção militar. Assim, o partido apresentava-se como liberal e, ao mesmo tempo, expressava posições políticas bastante conservadoras. Crítico do Estado Novo, foi saudado anos depois como "o partido da Revolução de 1964" (BENEVIDES, 1981, p. 247-9).

Os udenistas conheceram sua primeira derrota em dezembro de 1945, quando seu candidato à presidência, o brigadeiro Eduardo Gomes, foi vencido pelo general Eurico Gaspar Dutra, apoiado pelo PSD e PTB. Ao longo de seu mandato (1946-1951), Dutra aproximou-se dos grupos conservadores, formando uma grande coalizão. Na política externa, houve forte alinhamento diplomático com os Estados Unidos. Em 1947, o Tribunal Superior Eleitoral cassou o registro do Partido Comunista Brasileiro (PCB) e, no ano seguinte, todos os parlamentares vermelhos perderam seus mandatos.

Enquanto Dutra esteve na Presidência, a diplomacia argentina tentou, em inúmeras ocasiões, aumentar sua aproximação com o Brasil, seu terceiro maior parceiro 
comercial. O resultado, no entanto, ficou aquém do esperado. Ainda que Dutra, Perón e Evita tenham se encontrado na cidade de Uruguaiana, em 1947, não existiram grandes avanços em termos diplomáticos e políticos. De acordo com o historiador luri Cavlak (2008, p. 56-67), a política externa dutrista, ao incorporar diretrizes de Washington, adotou uma postura de obstrução à integração regional, o que dificultou a assinatura de acordos de cooperação. Além disso, tais iniciativas eram rejeitadas pela UDN e por um setor do próprio Ministério das Relações Exteriores (Itamaraty), órgão com quadros politicamente conservadores que, geralmente, não viam com bons olhos o regime platino.

Por conseguinte, era grande a expectativa argentina em torno da vitória de Getúlio Vargas nas eleições presidenciais de outubro de 1950. Esperava-se que seu retorno representasse uma guinada nos rumos da política externa brasileira, já que o político gaúcho tinha semelhanças em relação a Perón. Na ocasião, a imprensa portenha controlada pelo governo publicou duras críticas à diplomacia de Dutra e fez explícita campanha a favor de Vargas (CAVLAK, 2008, p. 56-57). Essa troca de gentilezas, aliada às visitas de líderes do seu partido (PTB) a Buenos Aires, acabou por levantar suspeitas de que a candidatura getulista estivesse recebendo dinheiro da Casa Rosada. João Goulart (Jango), então deputado estadual, foi apontado como um dos intermediadores do suposto financiamento.

Os rumores não impediram que Vargas fosse eleito presidente com pouco mais de $48 \%$ dos votos válidos. Saiu derrotado novamente o candidato da UDN, brigadeiro Eduardo Gomes. Durante o mandato inconcluso (1951-1954), o presidente brasileiro enfrentou uma ferrenha oposição do Poder Legislativo e da maioria da imprensa. Uma parte da UDN, em especial, tornou-se cada vez mais intransigente.

Naqueles anos, boatos sobre uma aliança secreta entre trabalhistas e justicialistas foram especialmente constantes nos periódicos antigetulistas. Eles se avolumaram principalmente a partir da indicação de João Goulart para Ministro do Trabalho, Indústria e Comércio, em junho de 1953. Jornais como Tribuna da Imprensa difundiram à exaustão a ideia de que o jovem e popular líder gaúcho estaria se aproximando dos sindicatos para construir uma base eleitoral que ampliasse o poder dos trabalhistas no Congresso. Assim, 
seria possível reformar a Constituição, criar a possibilidade de reeleição ilimitada e garantir a continuidade do grupo no palácio do Catete. Grosso modo, seria essa a estratégia dos líderes do PTB para criar uma suposta "república sindicalista". Tal expressão foi muito utilizada pela oposição para imputar aos trabalhistas um projeto político autoritário - a criação de regime discricionário baseado nos sindicatos semelhante àquele que, alegavam, já existia na Argentina (SANTOS, 2015, p. 134-148).

A governabilidade de Vargas se complicou ainda mais em março de 1954 quando, a partir da divulgação de um discurso secreto de Perón, o líder gaúcho passou a ser acusado de firmar acordos sigilosos com a Argentina sem o consentimento do Congresso. Os insistentes rumores em torno do Pacto $A B C$ deram origem, junto com outras acusações, a um processo de impeachment do presidente brasileiro, que foi rejeitado no Congresso em junho daquele ano. Salvo, o governo ficou ainda mais desgastado e terminou de maneira trágica dois meses depois.

Ao final, Brasil e Argentina não firmaram acordos econômicos e diplomáticos significativos naqueles anos. Perón e Vargas, tidos por alguns autores como exemplos do populismo latino-americano3 ${ }^{3}$, sequer chegaram a se conhecer pessoalmente.

\section{O jornal Tribuna da Imprensa}

Carlos Lacerda já era conhecido no circuito político e jornalístico do Rio de Janeiro quando lançou Tribuna da Imprensa, em 27 de dezembro de 1949. Na versão de seu proprietário, o jornal vespertino teria nascido de uma campanha popular organizada por seus amigos, que angariou acionistas desejosos de "dispor de um veículo de comunicação que fosse, acima de tudo, imparcial e dissesse a verdade” (MENDONÇA, 2002, p. 100). Embora Lacerda insistisse no caráter popular dos fundos levantados para a criação do diário, a historiadora Marina Gusmão de Mendonça demonstrou o contrário. Segundo a autora:

\footnotetext{
${ }^{3}$ Propositalmente, deixa-se de lado aqui a vastíssima bibliografia a respeito da expressão populismo e evitase usá-la porque, como defende Maria Helena Rolim Capelato (2008), as especificidades de cada regime político tendem a ser obliteradas nessas interpretações generalizantes.
} 
É muito mais provável que o surgimento da Tribuna da Imprensa tenha resultado da mobilização de grupos empresariais vinculados ao capital externo ante o nacionalismo que começava a tomar conta de setores do Exército e da própria burguesia industrial, e que conseguira paralisar a tramitação de um projeto governamental que garantiria participação de investimentos estrangeiros na exploração do petróleo.

O simples exame da relação dos maiores acionistas corrobora essa tese, bem como a constatação de que, entre os principais organizadores e, posteriormente, dirigentes da empresa, estavam figuras de proa do empresariado, com notórias vinculações externas, ou, ao menos, pessoas que com esses grupos mantinham estreitas ligações (MENDONÇA, 2002, p. 101-102).

Ainda que fosse influente e incomodasse os adversários, o “jornal do Lacerda" 4 nunca atingiu grandes tiragens ${ }^{5}$. Isso não impediu que o diário configurasse uma excelente plataforma política, que garantiu ao seu proprietário popularidade cada vez maior, especialmente entre a elite e classe média carioca. Dono de retórica exuberante e ferina, Carlos Lacerda frequentemente colocava-se como puritano defensor do povo. Sua autoimagem de salvador da nação associava-se à insistente denúncia maniqueísta de que a população estava sendo continuamente explorada por corruptos vilões.

Cotidianamente, o jornalista descarregava sua metralhadora de denúncias contra autoridades, especialmente dos partidos ideologicamente inimigos. Se por vezes ajudou a elucidar abusos e contravenções, não raro ficava evidente que muitos de seus argumentos se baseavam em suspeitas com indícios frágeis. Sua retórica assemelhava-se, em linhas gerais, ao discurso da própria UDN, que se tornou mais moralista na medida em que perdeu eleições presidenciais consecutivas.

Segundo Maria Victoria de Mesquita Benevides (1981, p. 212), a UDN possuía uma autoimagem de excelência de seus integrantes, o que a levou a se colocar com frequência

\footnotetext{
${ }^{4}$ Esse personalismo foi corroborado por depoimentos do período. Aluísio Alves, então redator-chefe do periódico, relatou certa vez que uma das dificuldades do cotidiano era o "método de Lacerda, que participava de tudo, escrevia do seu artigo a pequenas notas, acompanhava todas as seções do jornal, orientava, reclamava, modificava, numa velocidade de trabalho difícil de acompanhar" (RIBEIRO, 2007, p. 148).

5 No auge, em 1954, publicava 40 mil exemplares diários, enquanto vários outros vespertinos, como O Globo e Última Hora, atingiam 110 mil e 92 mil exemplares, respectivamente (RIBEIRO, 2007, p. 60).
} 
como um "pedaço de chão limpo", decente e digno em relação aos demais. Essa ideia de “partido incorruptível” era reforçada pela atuação parlamentar centrada nas constantes denúncias de desvios administrativos, de subversão da ordem provocada pelas políticas trabalhistas e da suposta infiltração comunista na sociedade.

Figurava como principal chargista de Tribuna da Imprensa a artista plástica Hilde Weber. Nascida e formada na Alemanha, ela imigrou ao Brasil em 1933 e passou por vários jornais e revistas do Rio de Janeiro. Em 1950, foi contratada por Carlos Lacerda para atuar em seu recém-lançado jornal. Ali, publicou quase que diariamente deus desenhos de humor até 1962, quando se transferiu para O Estado de S. Paulo, onde trabalhou até se aposentar, em 1989.

Dona de um estilo sintético, de "ar apressado" e traços fortes, ela comentou, em um depoimento colhido por Herman Lima (1963, p. 1604), algumas de suas preferências como artista: “o desenho a traço, que é o mais puro, é sinônimo de 'eliminar': desenhar a traço é dizer tudo com pouco". Sua obra também foi definida por Fernando Pedreira (apud WEBER, 1986, p. 4):

Não parece haver nos seus desenhos inquietação, pesquisa formal e, ainda menos, a deliberada versatilidade criadora de um Chico Caruso ou do mestre Millôr Fernandes. A personalidade de Hilde é estável. Tranquila, firme como um barco seguro de sua rota. Mas ela se separa dos seus colegas brasileiros (também dos mais antigos como J. Carlos ou Calixto), talvez mais ainda pelas suas origens artísticas. Hilde descende do expressionismo alemão, de um George Crosz [sic], embora as charges não tenham em geral nem a virulência, nem a consciência social antiburguesa, que tanto marcaram os grandes expressionistas europeus.

Em relação à sua postura ideológica, Motta (2006, p. 12) notou que, em consonância com o projeto de Tribuna da Imprensa, a obra de Hilde se aproxima do ideal liberal e tem características marcadamente antiesquerdistas e anticomunistas. Antes que Lacerda tivesse seus direitos cassados pela ditadura militar, por exemplo, ela chegou a assinar caricaturas exaltando sua atuação política e defendendo sua candidatura presidencial.

No entanto, não é possível aprofundar suas posições políticas pessoais, dada a pouca disponibilidade até o momento de material bibliográfico a esse respeito. É difícil 
saber ao certo em que medida as charges ilustram a visão de mundo da artista ou a de seus colegas e chefes de redação. As caricaturas eram solicitadas pela direção ou, na maioria das vezes, brotavam da cabeça da artista após as reuniões de pauta? Difícil saber. É provável que as duas situações fossem comuns. Afinal, jornais devem ser entendidos como empreendimentos coletivos de indivíduos que possuem um conjunto mínimo de valores políticos comuns, ou seja, certa comunhão ideológica.

Nesse sentido, vale lembrar o que escreveu o historiador francês Jean François Sirinelli (apud LUCA, 2005, p. 140), para quem “jornais e revistas não são obras solitárias”, mas "empreendimentos que reúnem um conjunto de indivíduos, o que os torna projetos coletivos, por agregarem pessoas em torno de ideias, crenças, e valores que se pretende difundir a partir da palavra escrita"; ou seja, os órgãos de imprensa são atores fundamentais nas disputas políticas, pois tendem a ser um "ponto de encontro de itinerários individuais unidos em torno de um credo comum". Assim, embora Tribuna da Imprensa fosse composta por diversos jornalistas e articulistas que tinham visões políticas múltiplas, não se pode deixar de supor alguma identificação ideológica mínima entre aqueles que integravam esse meio de comunicação.

Entre dezembro de 1949 e dezembro de 1955, Tribuna da Imprensa lançou cerca de 1.800 números. Verificando-os em sua totalidade, nota-se que, em pelo menos 52, foram veiculadas charges com nítidas referências ao peronismo, totalizando cerca de 2,9\% dos exemplares. São analisadas a seguir algumas caricaturas consideradas significativas das principais representações ${ }^{6}$ expressas nesses desenhos satíricos. Buscou-se compreendêlas dentro do contexto político do período.

\section{Perón, o déspota}

Em Tribuna da Imprensa, as críticas ao peronismo estiveram frequentemente vinculadas à defesa dos direitos individuais, em especial da liberdade de expressão. Inúmeros editoriais, reportagens e charges foram publicados para denunciar o crescente

\footnotetext{
${ }^{6}$ Esse conceito é pensado a partir da acepção do historiador francês Roger Chartier (1991). Para ele, as representações dão sentido ao mundo ao permitir o trabalho de "classificação e de recorte que produz configurações intelectuais múltiplas pelas quais a realidade é contraditoriamente construída pelos diferentes grupos que compõem uma sociedade" (CHARTIER, 1991, p. 183). Ao mesmo tempo que tornam inteligível o real, as representações ajudam a produzi-lo de acordo com interesses sociais mais diversos.
} 
autoritarismo do regime argentino. Sob tal prisma, o jornal se colocava como paladino do liberalismo.

As charges quase sempre destacaram a figura de Perón como o principal protagonista da situação argentina. Tratava-se de um viés bastante maniqueísta que buscava personificar no presidente argentino o único responsável por toda uma complexa gama de mudanças coletivas que vinham ocorrendo. A solidão de Perón, presente em muitas caricaturas, deixa implícita a denúncia de que uma única pessoa seria a responsável pela destruição das instituições democráticas. Ali, ele é retratado como mais um ditador?

Não foram identificados desenhos de humor que zombassem da população argentina ou que poderiam denotar rivalidade em relação ao Brasil. Essa ausência está em consonância com o que se pode ler em muitos editoriais nos quais os argentinos foram, grosso modo, poupados de críticas. Para articulistas como Lacerda, a população não atuava como agente político no peronismo. Seria, em realidade, vítima de um grande mal que, inspirado na experiência nazista, impunha o silêncio absoluto a todos.

Alto para os padrões do período (com pouco mais de 1,80 m), Perón foi retratado quase sempre com um longo nariz e com boca e queixo proeminentes. Frequentemente foi desenhado como um oficial longilíneo. No entanto, em algumas ocasiões, também apareceu como um homem balofo e desalinhado. Como recurso para caracterizá-lo, Hilde lançou mão constantemente do recurso da faixa presidencial com a bandeira argentina que cruzava o peito e do tradicional quepe militar. Ele aparece quase sempre com um semblante fechado, em oposição às fotografias divulgadas oficialmente, que o mostravam com um belo sorriso.

A acusação de filiação nazifascista pode ser observada na Figura 1. Como um fantasma, o líder do Terceiro Reich emana dos livros queimados e cumprimenta o presidente argentino (“Heil”), que é representado baixo, gordinho e com cara amarrada. A imagem provavelmente faz referência à repressão à cultura e à imprensa que estavam ocorrendo na Argentina naquele momento. A artista procurou estabelecer um paralelo

\footnotetext{
7 Vale destacar que, inversamente, a forte propaganda peronista também era profundamente personalista, responsabilizando o presidente argentino por todos os êxitos do regime.
} 
entre tal situação e os espetáculos públicos de queima de livros ocorridos na Alemanha nazista em 1933. Ao lado do desenho, publicou-se um editorial de Lacerda em que Perón era apontado como discípulo aperfeiçoado de Vargas. Também foram destacadas as características autoritárias de seu governo e sua admiração, junto com outros membros do GOU, pelos países do Eixo durante a Segunda Guerra.

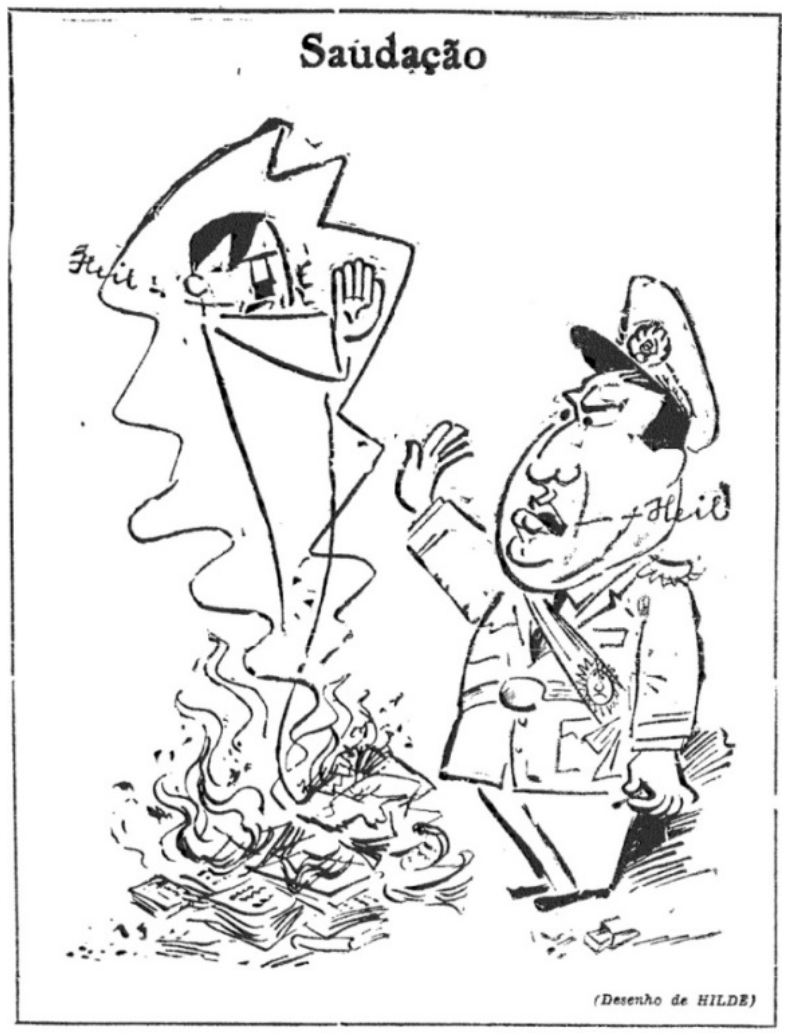

Figura 1 - HILDE.

Fonte: Tribuna da Imprensa, Rio de Janeiro, 17/04/1953, p. 4.

Jornais antigetulistas criticavam especialmente $\mathrm{o}$ autoritarismo do regime argentino em relação à imprensa. Era uma forma de apontar a ilegitimidade do governo platino e seu respeito meramente retórico pela democracia. Nessas ocasiões, com frequência Lacerda estabelecia paralelos e lembrava que a liberdade de expressão era muito recente no Brasil, país que saíra há pouco da ditadura do Estado Novo estabelecida por Getúlio Vargas.

No primeiro semestre de 1951, desenrolou-se uma longa batalha política que culminou na expropriação, por um Congresso amplamente controlado por peronistas, do diário portenho La Prensa. Não se tratava de um periódico qualquer, mas de um 
tradicional e influente matutino que, nas palavras do historiador estadunidense James Cane (2011, p. 1), figurava como "o mais poderoso jornal comercial da América Latina”. Para os opositores ao regime, a violência contra La Prensa era mais um sinal inequívoco de seus pendores autoritários. Para os apoiadores, tratava-se de um ato revolucionário altamente simbólico, porque derrubava um dos pilares das oligarquias.

A medida teve ampla repercussão em todo o mundo ocidental e foi criticada em vários meios de comunicação brasileiros. Um mês antes da expropriação se confirmar, Hilde publicou uma charge (Figura 2) na qual denunciou o fechamento arbitrário do jornal, representado por um soldado armado junto à porta lacrada. No primeiro plano, aparecem dois personagens fundidos em um - Perón e sua esposa, Evita. Enquanto o primeiro, com expressão grave, faz uma saudação que remete ao nazifascismo, a segunda dança alegremente. Esse movimento corporal remonta à sua origem como atriz de rádio e teatro. Seu sorriso despreocupado contrasta com o cenário sombrio. Em mais de uma ocasião, Lacerda condenou o que julgava ser uma "ditadura a quatro mãos, que caiu sobre a Argentina, como uma maldição" (LACERDA, 09/03/1951, p. 4).

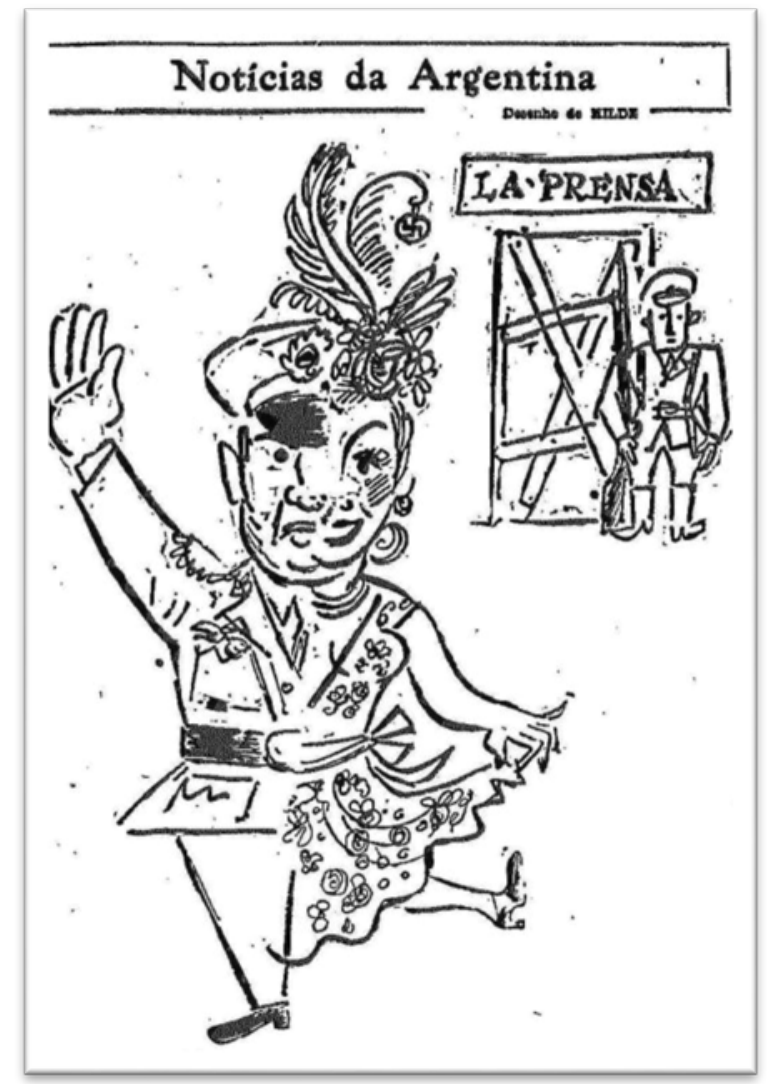

FIGURA 2 - Tribuna da Imprensa.

Fonte: Rio de Janeiro, 08/03/1951, p. 4. 
A suposta interferência de Perón na política externa do Brasil também foi denunciada em Tribuna da Imprensa. Em agosto de 1951, o deputado federal João Batista Lusardo (PSD-RS) foi indicado pelo presidente brasileiro para o cargo de embaixador do país na Argentina. Muito próximo a Vargas, Lusardo também cultivara boas relações com o presidente platino desde sua primeira passagem como embaixador em Buenos Aires (1946-1947). Há anos essa proximidade com o justicialismo era alvo de críticas e suspeitas por parte de políticos e jornalistas da oposição.

No lápis de Hilde (Figura 3), a indicação de Lusardo teria sido uma imposição ao presidente Vargas por parte de Perón que, com sua tradicional cara de poucos amigos, empunha um documento com a palavra ultimatum. Ao lado dele figura Lusardo, com um sorriso maroto. Em uma possível interpretação, a representação do embaixador com ar malandro remete a denúncias da época sobre o enriquecimento ilícito deste durante sua primeira passagem como diplomata pela capital argentina. Seu retorno ao cargo Ihe garantiria a continuidade dos lucros e negócios pessoais escusos - daí o ar de satisfação.

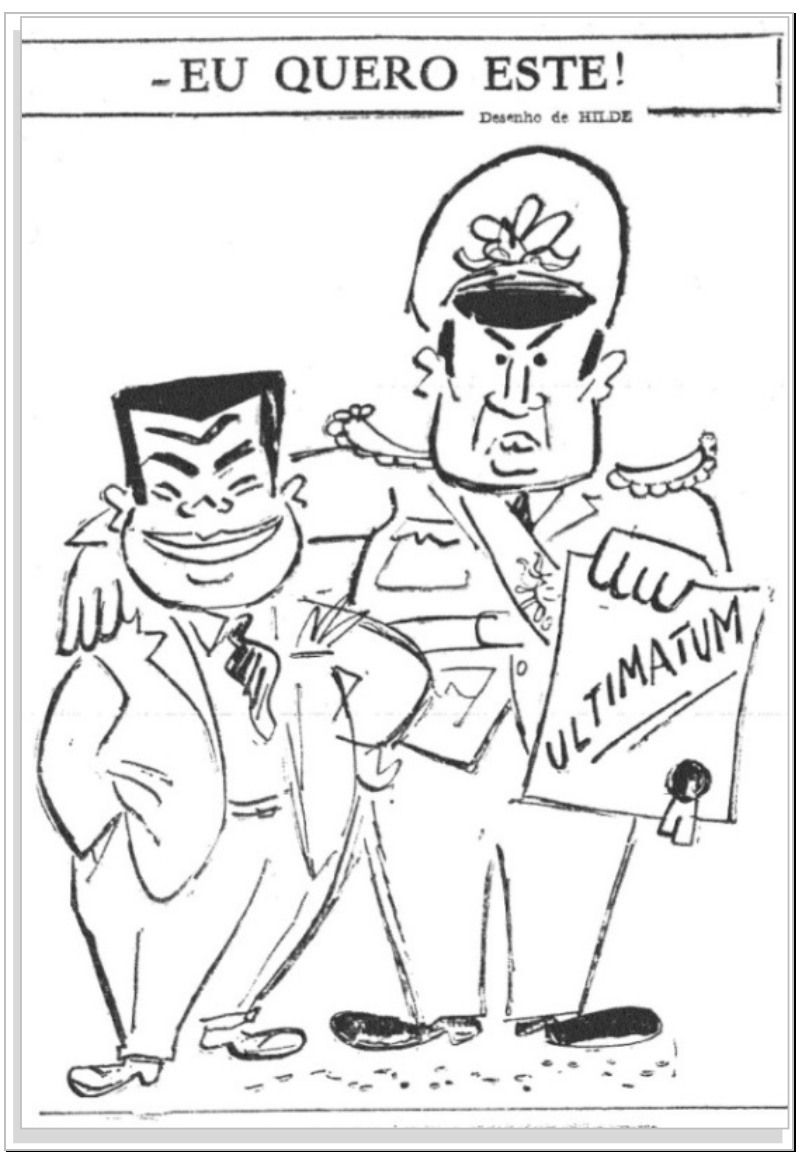

Figura 3 - HILDE.

Fonte: Tribuna da Imprensa, 18-19/08/1951, p. 4. 
Houve críticas também ao projeto de um amplo acordo econômico envolvendo Argentina, Brasil e Chile (Pacto $A B C$ ), defendido por Perón desde o início da década de 1950. Para meios de comunicação antiperonistas, tratava-se de uma armadilha do imperialismo platino que pretendia, a médio prazo, dominar a região. Em Tribuna da Imprensa, uma charge não assinada, provavelmente de Hilde, traduziu a ideia do Pacto $A B C$ como uma arapuca continental (Figura 4). Nela, Perón, em trajes aparentemente escolares, equilibra um bloco com as iniciais das três nações. Sua expressão facial não deixa dúvidas a respeito das intenções perversas do projeto. Abaixo, a legenda: “ $A B C$ (Argentina, Brasil e Chile), bloco político antiamericano, e outro grande sonho de Perón”.

Chama atenção o isolamento do presidente argentino na cena, ou seja, a ausência de líderes de Chile e Brasil que, subentende-se, estariam sendo manipulados. Também curiosas são suas vestimentas que, em outra chave de leitura, remetem à ideia de uma molecagem, uma travessura irresponsável. Há efeito cômico ao colocar o líder justicialista, tão sisudo e poderoso, em trajes pueris. Também fica implícita a ideia de que ele possuiria a personalidade de uma criança mimada e, ao mesmo tempo, megalomaníaca. Pode-se pensar ainda que, do ponto de vista do artista, o Pacto $A B C$ não passaria de uma aventura tão imatura e imprudente quanto uma brincadeira infantil.

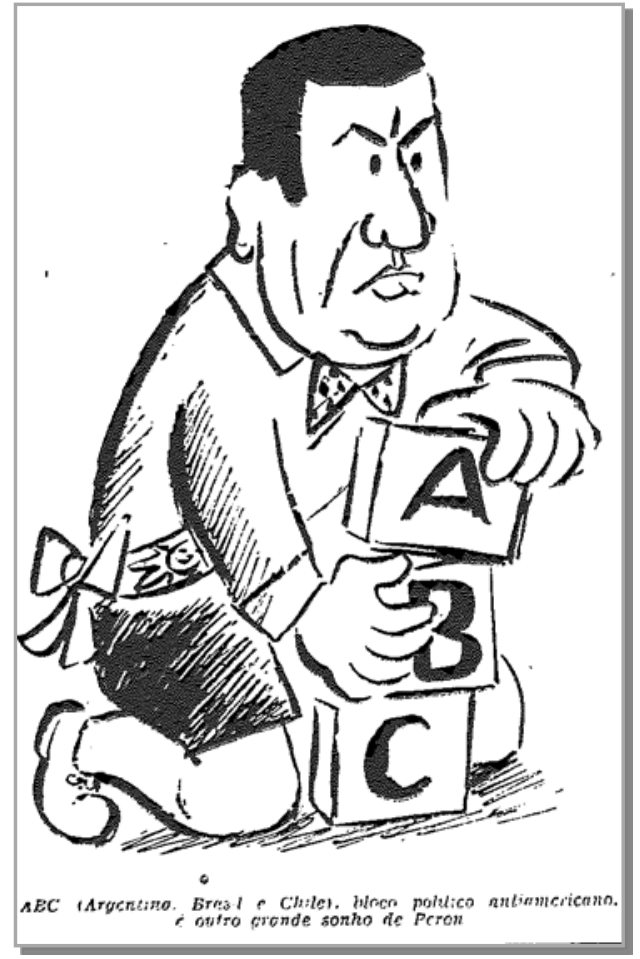

Figura 4 - Autoria desconhecida.

Fonte:Tribuna da Imprensa, 25/09/1952, p. 12. 
A imagem foi publicada junto a uma notícia que denunciava a "infiltração peronista" nos sindicatos brasileiros, promovida pelos adidos operários que trabalhavam na embaixada argentina. Outra reportagem semelhante assegurou que estava "em pleno desenvolvimento uma política acintosa de intromissão na vida pública, suborno de dirigentes sindicais e participação ativa em movimentos grevistas". Garantiu, ainda, que "300 agentes peronistas estão atualmente em atividade no Brasil”, incluindo aí “elementos nativos trabalhando a soldo" (CARLOS, 24/10/1952, p. 12).

\section{Os conspiradores}

O tema da conspiração também foi um dos mais abordados nas charges antiperonistas. A partir de notícias desencontradas, difundiu-se a noção de que, por meio de doações a campanhas eleitorais, treinamento militar e apoio armado, os peronistas estariam dispostos a ajudar secretamente os trabalhistas a criar no Brasil um regime semelhante ao justicialismo. Assim, o regime argentino não foi apresentado apenas como antimodelo, mas como ameaça real à democracia brasileira mediante a aliança sigilosa com políticos locais.

Do ponto de vista de udenistas, como Carlos Lacerda, a existência de um inimigo que agia nas sombras (os trabalhistas) legitimava que a mesma estratégia fosse colocada em prática por eles, que se arrogavam os verdadeiros democratas. Assim, ao justificar a necessidade de intervenção das Forças Armadas, o jornalista fluminense e outros correligionários astutamente conclamavam os "grupos esclarecidos" não para um golpe, mas para o que chamavam de um "contragolpe", que deporia um governo tido como inimigo da liberdade e prestes a "trair o país". Em sua visão maniqueísta, tratava-se de salvar o povo continuamente explorado por vilões corruptos e infiéis à nação.

Pouco mais de um mês após o lançamento do jornal, em dezembro de 1949, Hilde desenhou Vargas e Perón tranquilamente tomando chimarrão nos pampas (Figura 5). Juntos, parecem se deliciar com um churrasco intitulado "Departamento de Estado", órgão do governo estadunidense responsável pelas relações internacionais. Naquele momento, Getúlio Vargas, na condição de senador, continuava em sua fazenda em São 
Borja, Rio Grande do Sul, a poucos quilômetros da fronteira com a Argentina. Astutamente, ele ainda não confirmara sua participação nas eleições presidenciais vindouras, embora as especulações a respeito disso fossem constantes.

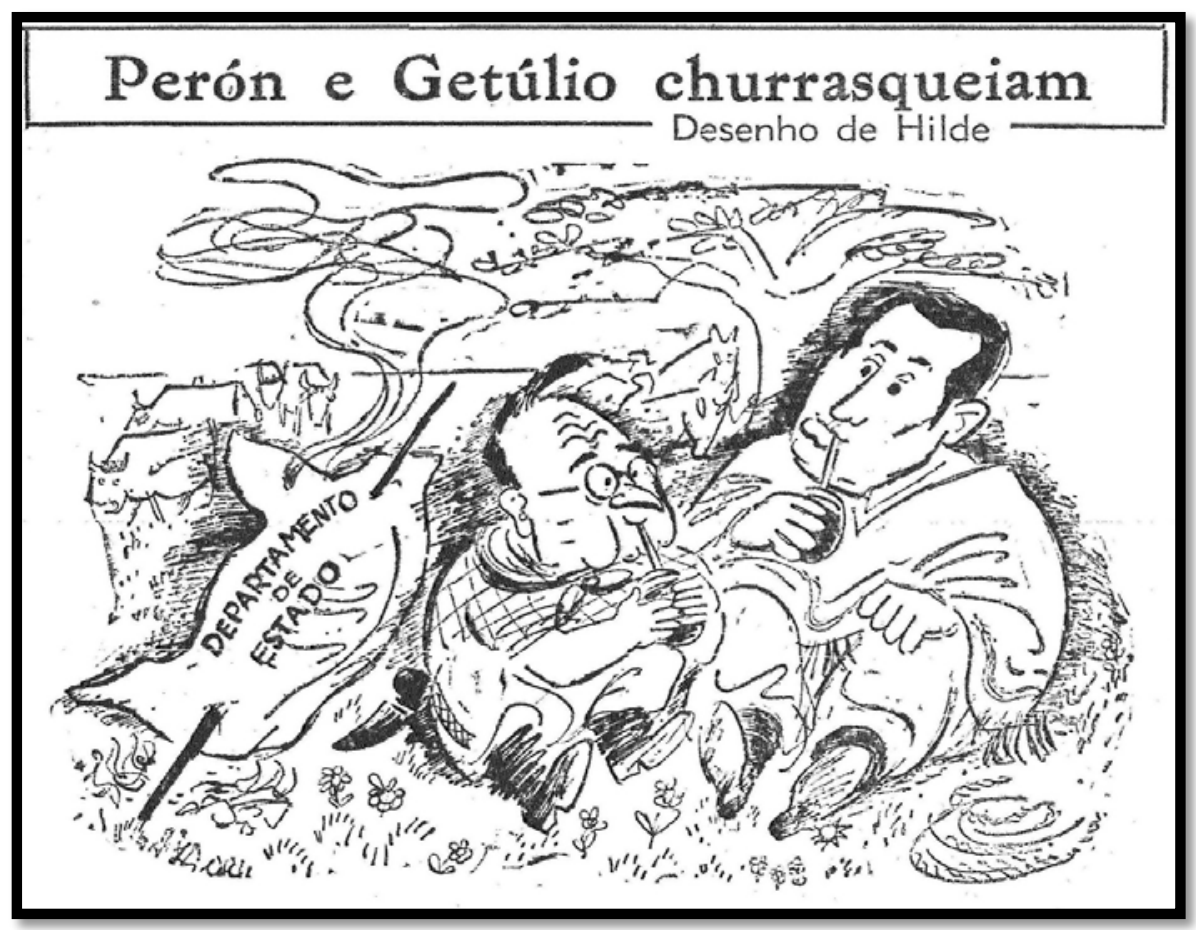

Figura 5 - HILDE.

Fonte: Tribuna da Imprensa, 25/01/1950, p. 4.

A caricatura faz clara referência às supostas conversas secretas entre os dois líderes, alvo de elucubrações na imprensa desde, no mínimo, 1948. Também aponta a postura contrária aos Estados Unidos por parte de ambos - os entendimentos secretos teriam por objetivo "devorar" os interesses de Washington na região. A retórica antiestadunidense e o não alinhamento geopolítico de Perón eram bem conhecidos. No caso de Vargas, seu discurso nacionalista também contribuía para que ele fosse reconhecido como um líder que não estava fortemente vinculado aos norte-americanos ${ }^{8}$. Do ponto de vista de Hilde, a aproximação entre esses dois políticos sul-americanos, que teriam uma identificação gauchesca, representaria um retrocesso aos interesses estadunidenses na região.

\footnotetext{
${ }^{8}$ Além disso, a atuação do Departamento de Estado, representado pelo embaixador Adolf Berle Jr., fora decisiva para o fim do Estado Novo (BANDEIRA, 2010, p. 222-3).
} 
Em 22 de junho de 1950, outra charge da artista alemã remeteu à ideia de conjura, tema que se tornou cada vez mais frequente nos diários antigetulistas, na medida em que se aproximavam as eleições presidenciais. Nela, Perón ensina planos políticos a Getúlio Vargas, Luis Carlos Prestes e Ademar de Barros (Figura 6) ${ }^{9}$.

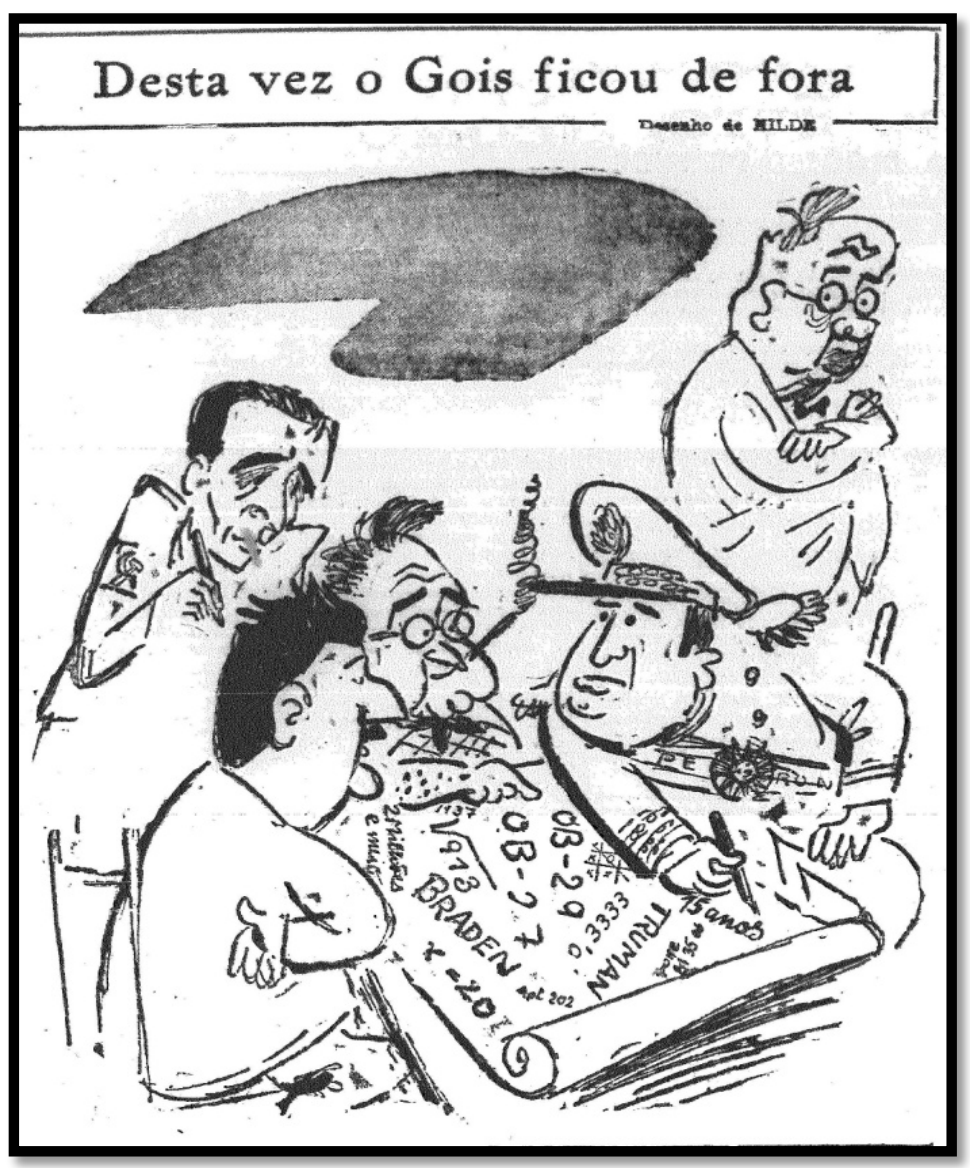

Figura 6 - HILDE.

Fonte: Tribuna da Imprensa, 22/06/1950, p. 4.

Hilde denuncia a possibilidade de Perón, que naqueles dias gozava de imensa popularidade, inspirar projetos políticos autoritários no Brasil, especialmente aquele liderado por Vargas em aliança com líderes apontados como antidemocráticos, como Prestes. O êxito do presidente argentino inspiraria a construção de um novo regime discricionário no país vizinho.

\footnotetext{
9 Uma semana antes, o controvertido governador de São Paulo anunciara, em um espetáculo público pomposo realizado na capital do estado, o que todos já sabiam desde o início do ano - ele daria amplo apoio ao postulante gaúcho (NETO, 2014, p. 177-8).
} 
Góes Monteiro, que naquele momento era senador por Alagoas (PSD), aparece descontente por não ter sido convidado. Figura central na implantação e organização do Estado Novo, período em que ocupou o cargo de Ministro da Guerra, andava distante de Vargas desde que liderara sua deposição em outubro de 1945. Ele, que participara de outros golpes de estado, dessa vez ficaria de fora ${ }^{10}$.

Embora empunhe um lápis, demonstrando sua possibilidade de contribuição ao bloco de políticos, o líder comunista Luis Carlos Prestes aparece em posição secundária. É o único não convidado a se sentar. Como se sabe, o Partido Comunista Brasileiro (PCB) se achava proscrito do cenário político nacional desde $1947^{11}$.

Dois meses depois dessa charge, em editorial contra a candidatura de Vargas intitulado "Traição à vista”, Carlos Lacerda fustigou:

A tolerância para com o sr. Getúlio Vargas, neste momento, significa a condescendência com um cúmplice de Perón. É preciso não esquecer que assim como Perón aprendeu com a ditadura do sr. Getúlio Vargas este modernizou muito o seu estilo ditatorial com as lições que lhe deu o marido da incandescente panfletária de Buenos Aires.

O sr. Getúlio Vargas encarna o peronismo no Brasil (LACERDA, 10/08/1950, p. 4).

Ainda que tenha aparecido com alguma força na imprensa durante a campanha, a noção de que Getúlio Vargas era o “candidato argentino" - ou seja, apoiado e financiado pelo governo da Casa Rosada - e que poderia "peronizar o Brasil” parece ter influenciado muito pouco o pleito. Em 3 de outubro de 1950, o político gaúcho foi eleito presidente com pouco mais de $48 \%$ dos votos válidos.

Isso não impediu que a representação de um conluio continuasse a ser insistentemente veiculada. Poucas semanas após as eleições, Tribuna da Imprensa publicou uma charge (Figura 7) na qual o presidente argentino aparece como ventríloquo a manipular Vargas. Não foi possível identificar o artista que a produziu, que assina

\footnotetext{
${ }^{10} \mathrm{Na}$ ocasião, ele já declarara seu apoio ao candidato do seu partido, Cristiano Machado, e em agosto de 1950 rejeitaria o convite de Vargas para ser seu candidato à vice-presidência na chapa PTB-PSP.

${ }^{11}$ Isolado, o partido na ilegalidade negou-se a apoiar qualquer candidato no pleito de outubro de 1950 e recomendou o voto em branco. Acredita-se, porém, que Vargas tenha recebido o apoio nas urnas de boa parte dos eleitores vermelhos.
} 
apenas como J. T. Na caricatura, Vargas, com roupa de palhaço, não passa de um títere guiado pelo tirânico e soturno líder argentino, que age fora dos holofotes. O presidente brasileiro estaria nas mãos de seu patrocinador. Nessa perspectiva, os destinos do país teriam sido vendidos ao estrangeiro e Perón seria, de fato, o novo presidente.

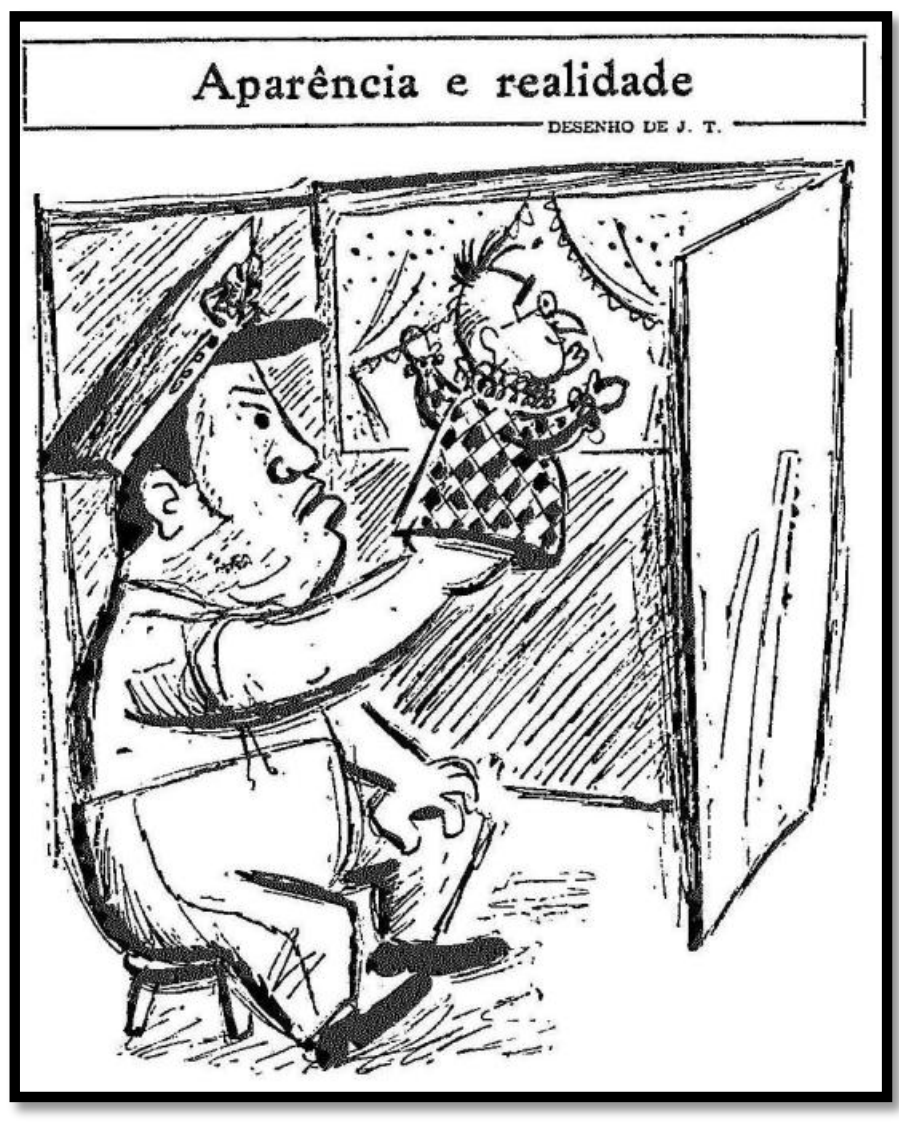

Figura 7 - J. T.

Fonte: Tribuna da Imprensa, 21/11/1950, p. 4.

Outra charge nesse sentido foi publicada em 1952, quando o jornal trouxe informações a respeito do monótono primeiro dia da $V$ Conferência dos Estados Americanos Membros da Organização Internacional do Trabalho, realizada em Petrópolis-RJ. Não havia nenhuma novidade. O único destaque ficou por conta do discurso inaugural de Vargas, em que ele louvara e prometera ampliação da legislação social brasileira. Minimizando as palavras do líder trabalhista, o jornalista Newton Carlos preferiu enfatizar a opinião do adido operário argentino. Este garantira: "o que disse Vargas é o mesmo que tem dito Perón" (CARLOS, 18/04/1952, p.1). O título da notícia ia nesse mesmo sentido: “Opinião dos pelegos argentinos: Vargas imita Perón”. 


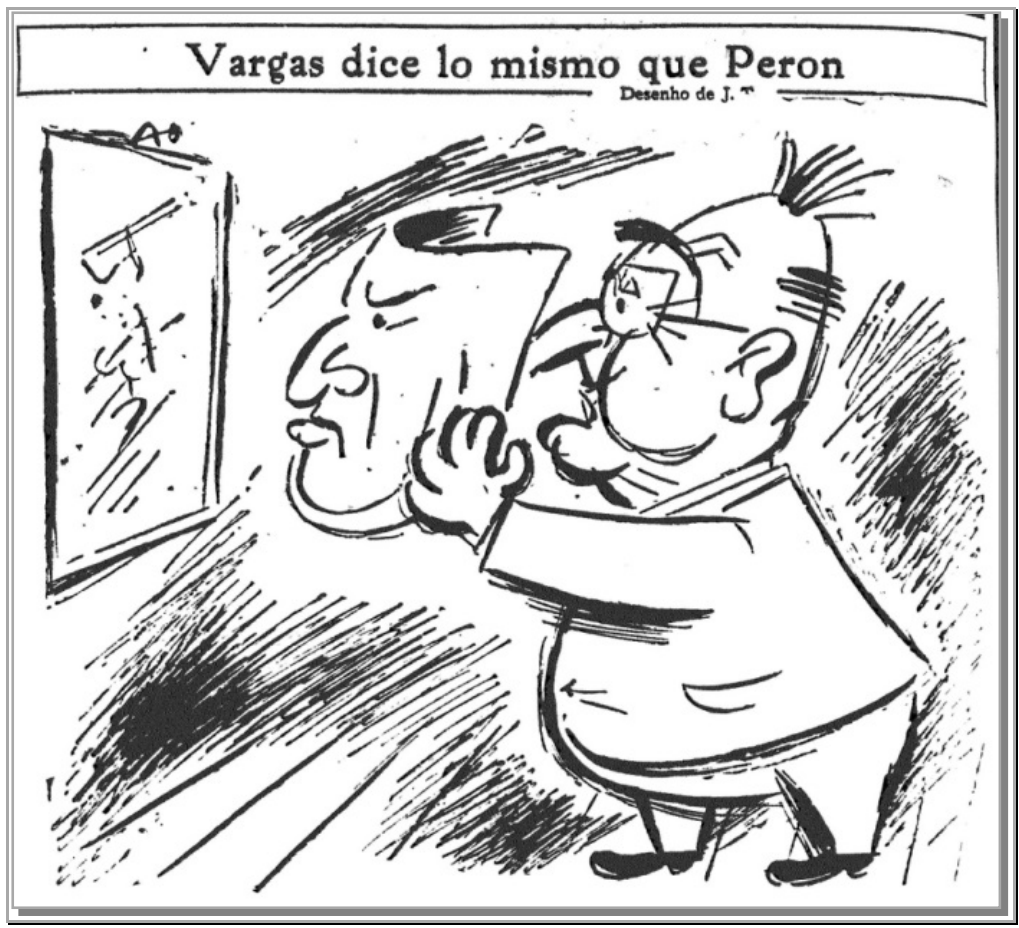

Figura 8 - HILDE.

Fonte: Tribuna da Imprensa, 19-20/04/1952, p. 4.

No dia seguinte a essa notícia, Hilde desenhou Vargas colocando uma máscara com a face do presidente platino (Figura 8). A imagem aponta o parentesco ideológico entre os dois. Novamente, não houve concessão ao líder justicialista, retratado com o semblante sisudo em alusão à maneira autoritária como lidava com seus adversários.

Em junho de 1953, Vargas indicou para ministro do Trabalho, Indústria e Comércio o então jovem deputado federal João Goulart (PTB-RS). Sua gestão marcou uma nova fase na relação com os trabalhadores, pautada principalmente pela abertura ao diálogo com os sindicatos, diminuição das medidas repressivas, estímulo à fiscalização da legislação trabalhista e mediação de acordos que colocaram fim a algumas greves (FERREIRA, 2005, p.107-109). A atuação do novo ministro fez dele um político muito popular. O sucesso, entretanto, gerou cólera proporcional por parte da oposição.

Para parte significativa dos antigetulistas, Jango, que já expressara publicamente sua admiração pelo chefe da Casa Rosada, era um novo Perón, pois estaria se fortalecendo no Ministério do Trabalho com o apoio dos sindicatos e dos comunistas, supostamente como fizera o presidente argentino. Em referência à sua notória vida boêmia, Lacerda deu a um de seus editoriais o título “Joãozinho Boa Pinta, demagogo de cabaré". No texto, atacou: 
Joãozinho Boa Pinta deve sair do ministério e voltar ao cabaré - que é a sua universidade, a sua caserna e o seu santuário. [...] O Brasil não está mais em idade de aturar as impertinências de um irresponsável. Ser ministro não é o mesmo que dançar tango (LACERDA, 05/08/1953, p. 4).

A atuação de João Goulart provocou forte reação também nos quartéis. Ela culminou na veiculação do "Manifesto dos Coronéis", assinado por 82 oficiais da ala conservadora do Exército no Rio de Janeiro. Após a publicação do documento, o jovem ministro foi exonerado, a contragosto de Vargas, no final de fevereiro de 1954. Nos traços de Hilde Weber, a saída de Jango foi comemorada com uma referência mordaz ao justicialismo. Demitido, o político gaúcho voltaria à vida boêmia e à Argentina peronista, onde poderia bailar o tango (Figura 9).

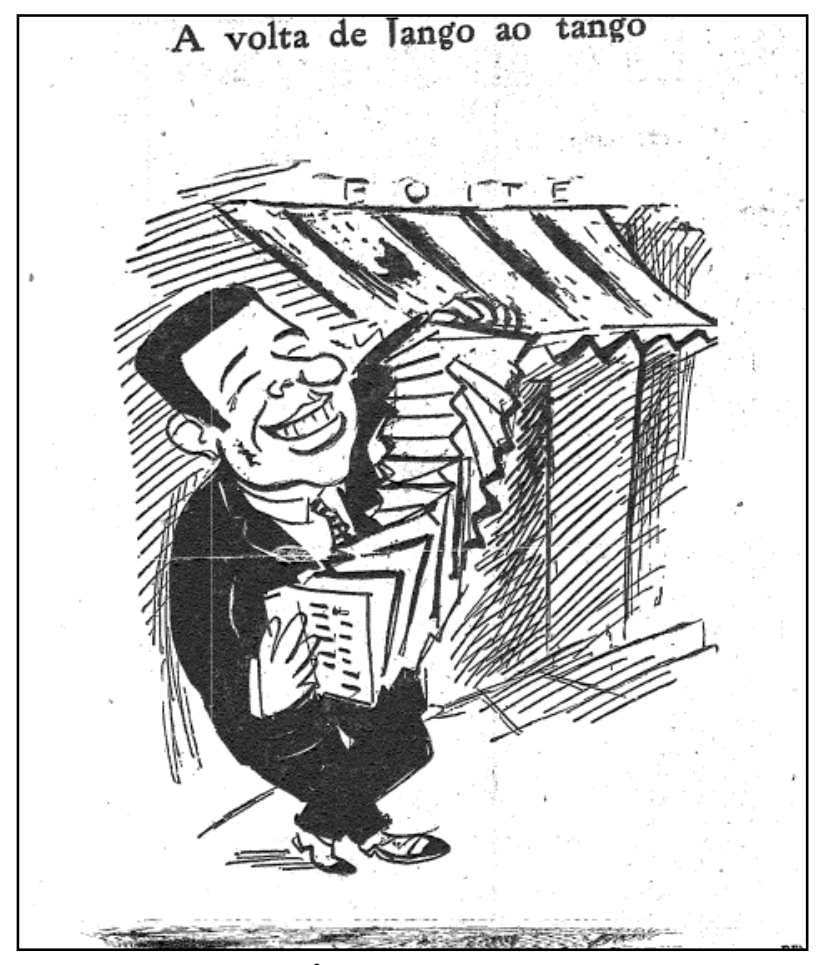

Figura 9. HILDE.

Fonte: Tribuna da Imprensa. 23/02/1954, $1^{\circ}$ caderno, p. 4.

As charges denunciando conluios foram veiculadas com mais frequência quando Tribuna da Imprensa divulgou, em um furo de reportagem, um discurso informal e secreto que Perón fizera aos militares na Escola Superior de Guerra, em Buenos Aires, em 11 de novembro de 1953. No pronunciamento, ele relatou entendimentos sigilosos com Getúlio Vargas antes das eleições de 1950 no sentido de formar o Pacto ABC. Se confirmados, os fatos narrados pelo chefe da Casa Rosada comprometeriam significativamente o 
presidente brasileiro. "Traição à pátria” foi a expressão mais utilizada pela oposição para reprovar a atuação de Vargas no caso.

É a isso que se refere a Figura 10. O pequenino Getúlio (cerca de 1,60 de altura), que agiria na escuridão, pede silêncio a Perón após serem descobertos em seus planos secretos (“Fomos pegados!"). A lanterna da cena pode remeter a, pelo menos, dois aspectos. Em primeiro lugar, era o símbolo do próprio jornal e estava relacionada ao ideal de objetividade da imprensa que reivindicava o posto de reveladora da verdade, ou seja, promotora das luzes. Nesse sentido, também é curiosa a descoberta do "crime" por várias pessoas e não apenas uma. Isso alude à tradicional noção do jornalismo como porta-voz da opinião pública, ou seja, meio de expressão de toda a sociedade e não de interesses particulares. Em segundo lugar, vale lembrar que Lacerda e outros udenistas haviam fundado em 1953 um grupo de militares e civis de postura radicalmente antigetulista e anticomunista que carregava o sugestivo nome de "Clube da Lanterna" (BENEVIDES, 1981, p. 86).

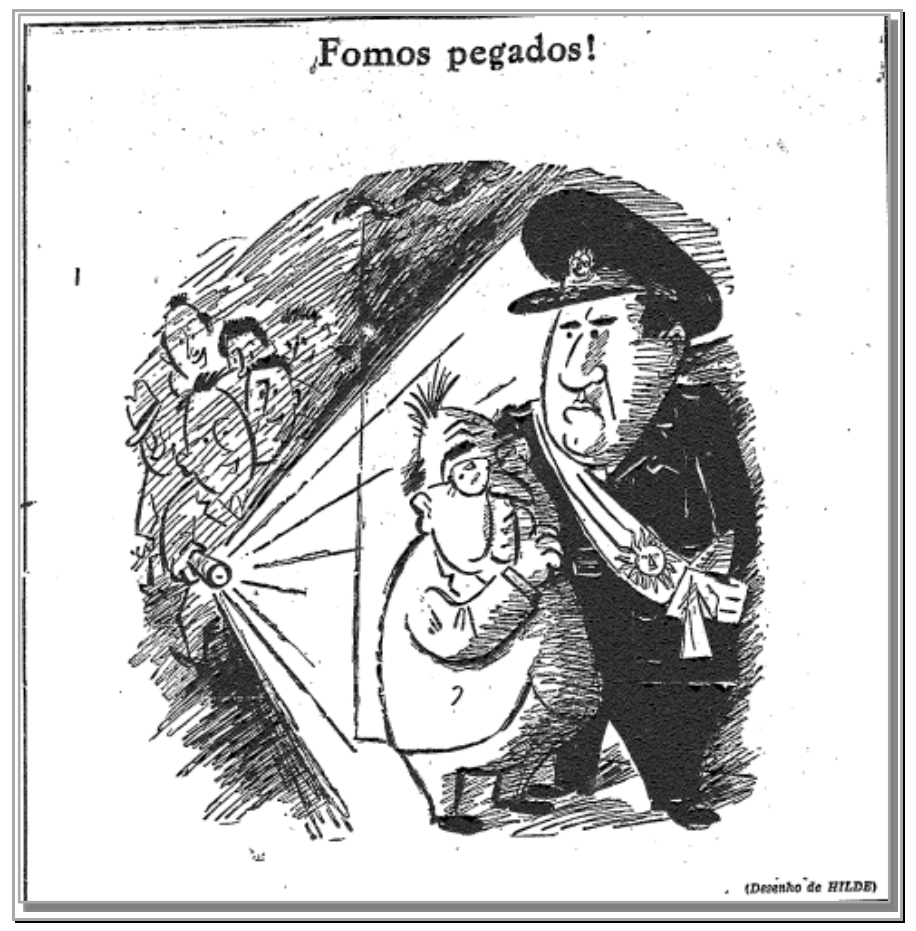

Figura 10 - HILDE.

Fonte: Tribuna da Imprensa, 17/03/1954, p. 4.

A derrota do pedido de impeachment de Vargas, que trouxera como uma das principais acusações os acordos secretos com a Argentina, e o desfecho trágico de seu 
governo apenas dois meses depois não aplacaram as representações em torno de um conluio entre a esquerda trabalhista brasileira e os justicialistas.

No ano seguinte, especificamente em 17 de setembro de 1955, Tribuna da Imprensa divulgou a carta Brandi. De acordo com esse documento, João Goulart (PTB), então candidato à vice-presidência na chapa com Juscelino Kubitschek (PSD), estaria envolvido na compra de armas da Argentina peronista e na preparação de "brigadas de choque operárias".

Coincidentemente, no dia anterior tivera início um golpe militar que levaria à queda do regime peronista. Demonstrando expectativa com as duas novidades surgidas concomitantemente (carta Brandi e a queda do justicialismo), Hilde Weber publicou uma charge associando diversos políticos locais a Perón (Figura 11). Podem ser identificados, da esquerda para direita: Luís Carlos Prestes (secretário-geral do PCB, na ilegalidade), Oswaldo Aranha (velho aliado de Vargas e seu ex-ministro da Fazenda), Ernani do Amaral Peixoto (presidente do PSD fluminense, ex-governador do Rio de Janeiro e marido de Alzira Vargas) ${ }^{12}$, Juscelino Kubistchek (candidato à presidência pelo PSD) e João Goulart. O presidente argentino, recentemente derrubado do poder, já está estatelado no chão.

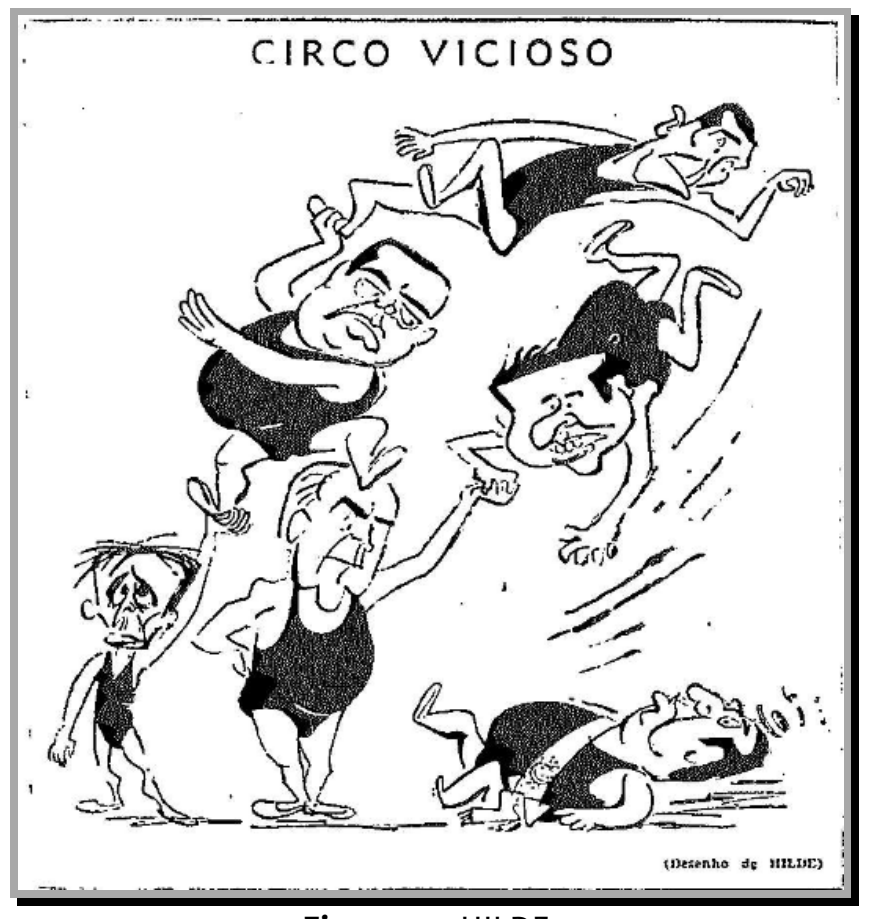

Figura 11 - HILDE.

Fonte: Tribuna da Imprensa, 29/09/1955, p. 4.

\footnotetext{
12 Também existe a possibilidade de que esse personagem da cena seja Lutero Vargas, filho do político
} gaúcho e presidente do diretório carioca do PTB. 
A imagem apresentou-os como malabaristas uniformizados de um mesmo espetáculo degradante (“circo vicioso"). Tendo em vista os acontecimentos recentes, a charge parece jactar-se do possível enfraquecimento de tais homens públicos que estavam direta ou indiretamente ligados à fórmula J-J (Juscelino-Jango). Eles seriam elos de uma mesma cadeia que teria começado a desmoronar a partir da destituição do líder platino e da veiculação da carta Brandi.

O próximo a se estatelar politicamente seria Jango, implicado diretamente no polêmico documento. Sua inevitável derrocada acabaria por atingir na sequência o candidato à presidência, Juscelino, e assim sucessivamente. É importante notar que o baixinho e franzino Prestes novamente desempenha papel discreto na cena, já que os comunistas seguiam sem direitos políticos.

Mesmo com a divulgação da carta Brandi, Goulart venceu o pleito por uma estreita margem de pouco mais de 200 mil votos. Soube-se em seguida, com base em análises grafológicas, que o documento era uma falsificação grosseira, produzida por dois argentinos que foram presos e indiciados. A participação de Lacerda no episódio permanece nebulosa até hoje. O desmascaramento da carta Brandi ajudou a desmoralizar a representação de um conluio entre trabalhistas e peronistas, que se enfraqueceu no imaginário político nos anos seguintes. Também colaborou para isso a própria queda do regime justicialista em setembro de 1955.

\section{Perón, tolo e malandro}

Muito presentes também, e geralmente cômicas, foram as charges que destacaram Perón como um espertalhão, responsável por ações impensadas que acabavam mal. Elas zombavam com frequência dos fracassos do líder justicialista, apontando-o como um palerma vaidoso. As duas representações (estúpido e espertalhão) tendiam a se complementar, pois, na visão da artista, o líder argentino, na ânsia de conseguir vantagens ilicitamente, acabava por cometer trapalhadas.

Em 1951, Hilde ridicularizou o anúncio do governo argentino de que havia realizado testes controlados em laboratório para produção de energia atômica (Figura 12). À época, 
Perón garantiu que o projeto secreto era de caráter pacífico e objetivava a produção de energia para fins industriais. No entanto, o principal responsável pelos experimentos, um cientista alemão desconhecido, de nome Ronald Richter, garantiu que o país já conhecia o segredo da bomba de hidrogênio e poderia produzi-la, se necessário. O anúncio foi recebido com enorme ceticismo pela imprensa e pelo meio científico internacional. Embora a Casa Rosada tenha se negado a dar detalhes adicionais, as extravagantes descrições técnicas de Richter tinham muito pouco a ver com as investigações do gênero feitas por soviéticos e estadunidenses.

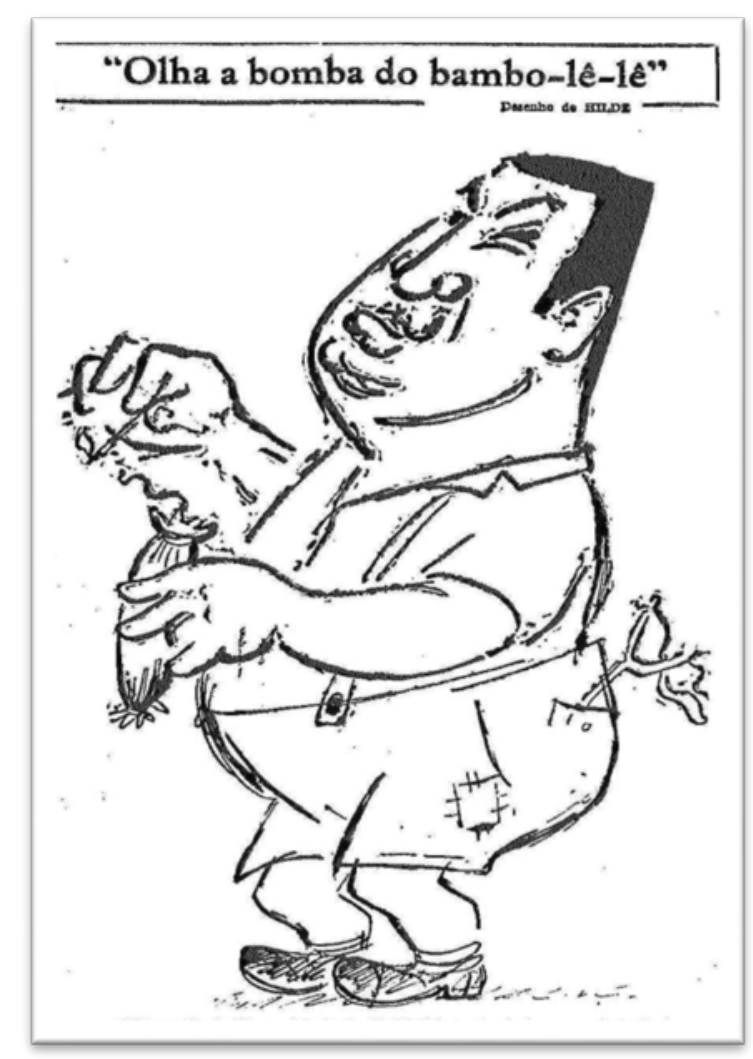

Figura 12 - HILDE.

Fonte: Tribuna da Imprensa, 27/03/1951, p. 4.

Na Figura 12, Perón aparece vestido como um menino, em roupas curtas e com estilingue no bolso. Nas mãos, carrega uma pequena bomba utilizada nos festejos de São João, em sinalização de que sua pretensa arma atômica não passaria de um embuste. Longe de uma expressão marota, seu rosto transmite a tradicional expressão grave de outros desenhos. Como um garoto arteiro, ele teria aprontado mais uma de suas traquinagens. O escrito no alto da charge ("Olha a bomba do bambo-lê-lê") relaciona-se 
ao editorial de Lacerda, publicado ao lado dessa caricatura, com o título: "A bomba do governo bambo".

Meses depois, Tribuna da Imprensa noticiou que um "encabuladíssimo" Perón havia ordenado a prisão de Richter, descrito como um "charlatão" que the passara um “conto atômico" (TRIBUNA DA IMPRENSA, 23/05/1951, p. 1). Naqueles dias, veiculou-se outro desenho bastante irônico (Figura 13). Com ar severo e usando o tradicional quepe e a faixa presidencial, o presidente argentino tem um momento como camponês e cuida de seus “cogumelos atômicos". Estes não passam de cogumelos tradicionais. A imagem faz referência às nuvens em forma de cogumelo que aparecem após as explosões atômicas. Novamente, o sentido é de zombaria em relação ao anúncio que, como comprovado posteriormente, era uma fraude grotesca ${ }^{13}$.

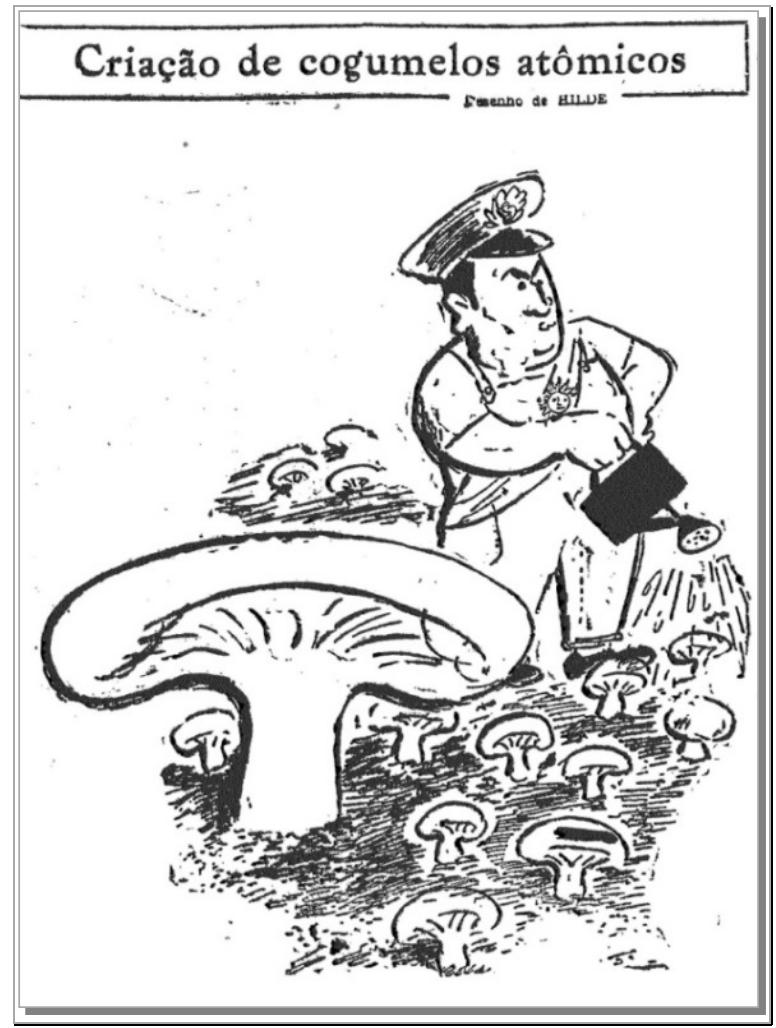

Figura 13 - HILDE.

Fonte: Tribuna da Imprensa, 28/5/1951, p. 4.

13 Malgrado as inúmeras objeções e desconfianças vindas do exterior, o presidente platino seguiu com seu sonho de obter enegria atômica barata e fácil por mais um ano e meio. Apenas no final de 1952 se chegou à conclusão de que as pesquisas de Richter realmente não passavam de um embuste, uma grande e caríssima fantasia que havia seduzido Perón. O enigmático Richter, que sequer era alemão e tampouco especialista em física nuclear, foi oficialmente demitido, o projeto foi paralisado e o assunto foi cuidadosamente jogado para escanteio na propaganda peronista. 
Outro episódio ocorrido em 1951 serviu de motivo para mais chacotas. $\mathrm{Na}$ comemoração do "Día de la Lealtad" peronista (17 de outubro), uma pequena nota da United Press informou que o Observatório Astronômico de La Plata descobrira um novo planeta e o batizara com o nome de "justicialista”. De acordo com declarações do reitor da universidade, a homenagem "significa a identidade da corporação universitária com os ideais do povo argentino em suas festas do corrente mês de outubro, consagrado à maior das virtudes humanas: a lealdade" (TRIBUNA DA IMPRENSA, 17/10/1951, p. 1).

No dia posterior à manchete, Hilde satirizou o presidente argentino, colocando sua grande cabeça como um planeta ao redor do qual girava um anel (Figura 14). Indiretamente, criticava-se a megalomania do regime e a atitude despropositada de atribuir o nome de um movimento político tido por demagogo a uma descoberta tão importante. Em outra chave de leitura, pode-se pensar que, na visão da artista, a cabeça de Perón continha pensamentos tão exóticos que só podia ser vista como um mundo à parte. Seus pensamentos seriam tão estranhos que pareciam originários de outra realidade.

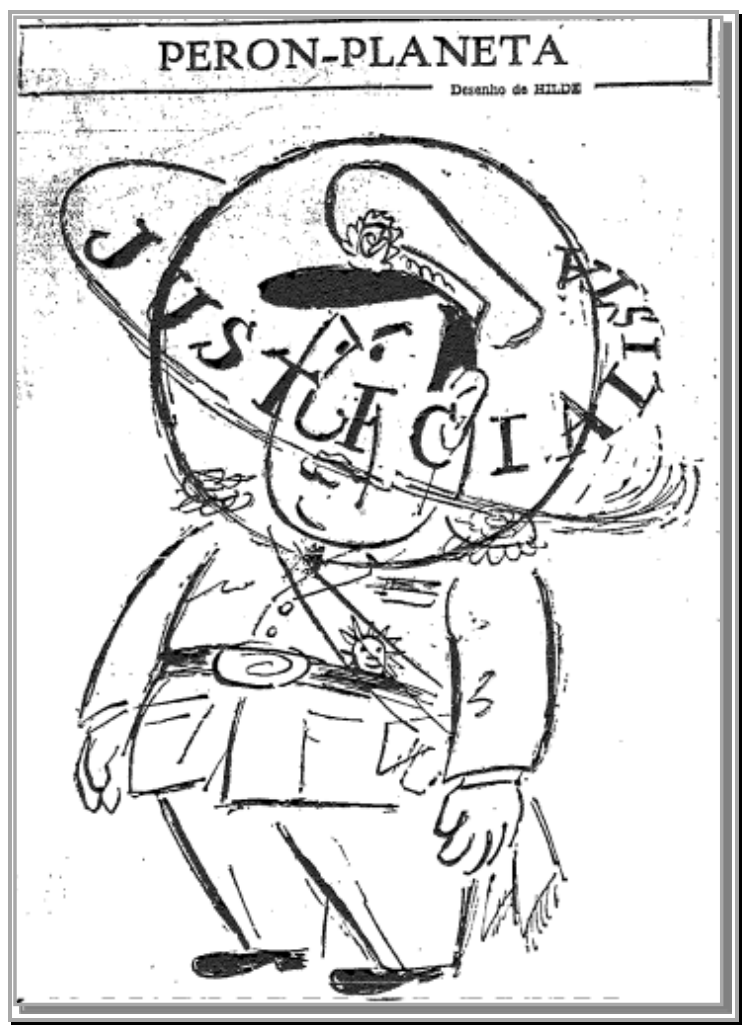

Figura $14-\mathrm{HILDE}$.

Fonte: Tribuna da Imprensa, 18/10/1951, p. 4. 


\section{Considerações finais}

As charges foram um importante instrumento de atuação política no período estudado. Por meio de uma linguagem própria, transmitiram mensagens alinhadas à posição político-ideológica de Tribuna da Imprensa.

A dinâmica de sua publicação evidencia isso. O tema das caricaturas esteve, com frequência, relacionado ao editorial de Carlos Lacerda, publicado ao lado da imagem, ou às notícias principais veiculadas naquele dia ou no dia anterior. Isso sugere que, ao menos na questão do peronismo, a produção da artista esteve fortemente ligada ao ponto de vista da redação. Nesse caso, as caricaturas funcionaram como crônica política, servindo principalmente para ilustrar a posição política do diário a respeito do assunto. Analisando a trajetória profissional da artista, pode-se supor certa comunhão ideológica entre suas opiniões e as do jornal em que trabalhava.

À primeira vista, parece não haver unidade nas representações das charges antiperonistas. Se, em algumas, Perón é retratado como um líder autoritário e poderoso, capaz de influenciar a política sul-americana, em outras aparece como bobalhão vaidoso e facilmente iludido ${ }^{14}$. Vale lembrar, porém, que, embora diferentes, essas representações fizeram parte do mesmo projeto de desconstrução do regime peronista integrado por Tribuna da Imprensa e muitos outros jornais conservadores brasileiros. Tratava-se de atacar o governo argentino por todos os flancos possíveis, pois, especialmente do ponto de vista de Lacerda, ele seria um mal absoluto a ser combatido diuturnamente.

Assim, pode-se afirmar que as charges integraram um programa mais amplo, cujo objetivo era negar o regime argentino como um todo e dificultar qualquer aproximação diplomática com o país vizinho. Notório anticomunista, Lacerda criticou duramente os projetos de integração regionais. Defendia a continuidade do projeto pan-americano liderado pelos Estados Unidos, país definido por ele como a "civilização fundada na liberdade".

\footnotetext{
14 Deve-se considerar, também, a existência de uma dinâmica própria desses desenhos de humor publicados nos jornais. Além de ilustrar o conteúdo dos editoriais, havia a necessidade cotidiana de provocar riso, o que ampliava bastante as dificuldades do ofício de cartunista. Esses imperativos levaram, ao que tudo indica, à produção de charges em que tão importante quanto denunciar era debochar. Para ficar em apenas um exemplo, ao produzir uma charge sobre o batismo de um planeta com o nome de justicialista, Hilde, muito provavelmente, não levou em conta a relevância dessa notícia, que saiu em uma pequena nota de rodapé. Importava, nesse caso, o potencial cômico que a novidade carregava.
} 
Vale notar ainda que os desenhos satíricos que enfatizavam a ideia de uma conspiração eram produzidos para atuar fortemente nas disputas político-partidárias brasileiras. Nesse sentido, as charges antiperonistas também foram armas políticas para questões nacionais. Buscava-se atribuir aos inimigos, os trabalhistas, práticas e projetos autoritários secretos, que colocariam em risco a democracia brasileira. Estrategicamente, essa insistente denúncia a respeito de um inimigo supostamente conjurador legitimava que estratégia semelhante fosse colocada em prática por alguns udenistas, que se consideravam os verdadeiros democratas. Assim, ao justificar seus contínuos apelos a soluções extralegais, como a intervenção militar, Lacerda e outros membros do partido argumentavam que se tratava de uma medida válida para combater opositores que agiam continuamente nas sombras.

Por fim, vale destacar que, em que pese o autoritarismo do regime justicialista, Tribuna da Imprensa ignorou que, ao menos em 1946, Perón fora eleito democraticamente. Além disso, desconsiderou, ao longo dos anos, qualquer tipo de avanço social, tachando continuamente medidas sociais de demagógicas. Embora eficiente ao propagar suas mensagens políticas, o periódico esteve distante de uma abordagem jornalística equilibrada e profunda. Analisadas em conjunto, as caricaturas de Hilde serviram para reforçar uma perspectiva profundamente maniqueísta.

\section{Referências}

ALMEIDA, Hamilton. Sob os olhos de Perón: o Brasil de Vargas e as relações com a Argentina. Rio de Janeiro: Record, 2005.

BANDEIRA, Luiz Alberto Moniz. Brasil, Argentina e Estados Unidos: conflito e integração na América do Sul (da Tríplice Aliança ao Mercosul), 1870-2007. 3. ed. revisada e ampliada. Rio de Janeiro: Civilização Brasileira, 2010.

BENEVIDES, Maria Victoria de Mesquita. A UDN e o udenismo: ambiguidades do liberalismo brasileiro (1945-1965). Rio de Janeiro: Paz e Terra, 1981.

CANE, James. The fourth enemy. Journalism and Power in the making of peronist Argentina, 1930-1955.Pennsylvania: The Pennsylvania State University, 2011. 
CAPELATO, Maria Helena Rolim. Multidões em cena: propaganda política no varguismo e no peronismo. 2. ed. São Paulo: Editora UNESP, 2008.

CARLOS, Newton. Opinião dos pelegos argentinos: Vargas imita Perón. Tribuna da Imprensa, Rio de Janeiro, 18 de abril de 1952, p. 1 e 10.

CARLOS, Newton. Reação do governo uruguaio. Tribuna da Imprensa, Rio de Janeiro, 24/10/1952, p. 12.

CAVLAK, luri. A política externa brasileira e a Argentina Peronista (1946-1955). São Paulo: Annablume, 2008.

CHARTIER, Roger. O mundo como representação. Estudos Avançados. São Paulo, v. 5, n. 11, abril. 1991.

FERREIRA, Jorge. 0 imaginário trabalhista: getulismo, PTB e cultura política popular (1945-1964). Rio de Janeiro: Civilização Brasileira, 2005.

LACERDA, Carlos. Traição à vista. Tribuna da Imprensa. Rio de Janeiro, 10 de agosto de 1950, p. 4.

LACERDA, Carlos. O Itamarati, o trust da Orquima e a tradição brasileira. Tribuna da Imprensa, Rio de Janeiro, 9 de março de 1951, p. 4.

LACERDA, Carlos. Joãozinho Boa Pinta, demagogo de cabaré.Tribuna da Imprensa, Rio de Janeiro, 5/8/1953, p. 4.

LIMA, Herman. História da caricatura no Brasil. Rio de Janeiro: José Olympio Ed., 1963, $4^{\circ}$ volume.

LUCA, Tania Regina de. História dos, nos e por meio dos periódicos. In: PINSKY, Carla Bassanezi (Org.). Fontes históricas. São Paulo: Contexto, 2005.

MENDONÇA, Marina Gusmão de. $O$ demolidor de presidentes. 2. ed. São Paulo: Códex, 2002.

MOTTA, Rodrigo Patto Sá. Jango e o golpe de 1964 na caricatura. Rio de Janeiro: Jorge Zahar Ed., 2006.

NETO, Lira. Getúlio: da volta pela consagração popular ao suicídio (1945-1954). 1. ed., São Paulo: Companhia das Letras, 2014. 
PERÓN prendeu Richter, o charlatão atômico. Tribuna da Imprensa, Rio de Janeiro, 23/5/1951, p. 1.

PLOTKIN, Mariano Ben. Mañana es San Perón: propaganda, rituales políticos y educación en el régimen peronista (1945-1955). 2. ed. Sáenz Peña: Editorial de La Universidad Nacional de Tres de Febrero, 2013.

RIBEIRO, Ana Paula Goulart. Imprensa e história no Rio de Janeiro dos anos 1950. Rio de Janeiro: E-papers, 2007.

SANTOS, Rodolpho Gauthier Cardoso dos. A construção da ameaça justicialista: antiperonismo, política e imprensa no Brasil (1945-1955). 2015. Tese (doutorado em História Social) - FFLCH-USP, São Paulo-SP, 2015.

TORRE, Juan Carlos. Introducción a los años peronistas. In: TORRE, Juan Carlos (Dir.) Nueva historia Argentina: los años peronistas (1943-1955). Buenos Aires: Sudamericana, 2002, Tomo VIII.

UM PLANETA para Perón. Tribuna da Imprensa, Rio de Janeiro, 17/10/1951, p. 1.

WEBER, Hilde. O Brasil em charge: 1950-1985. São Paulo: Circo Editorial, 1986. 